İş ve İnsan Dergisi | The Journal of Human and Work

Y1l | Year: Nisan | April 2020

Cilt-Say1 | Volume-Issue: 7 (1)

ss | pp: $119-135$

doi: $10.18394 /$ iid. 572572

e-ISSN 2148-967X

https://dergipark.org.tr/tr/pub/iid

Araştırma Makalesi

\title{
Öğretmenlerin Algıladıkları Örgütsel Desteğin Örgütsel Sonuçları Üzerindeki Etkisi: Bir Meta-Analiz Çalışması
}

\author{
The Effect of Perceived Organizational Support on Organizational Variables: A Meta- \\ Analysis Study
}

\section{Gamze Kasalak $^{\text {a }}$}

\section{MAKALE BİLGİSI}

Anahtar Kelimeler:

Algilanan Örgütsel Destek,

Örgüt-Iş Uyumu Sonuçları,

Davranıssal Sonuçlar, Öznel

Iyi Oluş Sonuçlarl, Meta-

Analiz

Tarihler:

Geliş 31 Mayıs 2019

Düzeltme geliș 17 Eylül

2019

Kabul 08 Ekim 2019
ÖZ

Bu araştırmanın amacı, öğretmenlerin algıladıkları örgütsel desteğin örgütsel sonuçlar üzerindeki etkisini belirten araştırmaların etki büyüklüklerini ortaya koymak ve elde edilecek etki büyüklüğünün; örneklem bölgesi ve eğitim kademesi moderatör değişkenlerine göre farklılık gösterip göstermediğini meta-analiz yöntemiyle araştırmaktır. Bu araştırmalardan ögretmenlerin algıladıkları örgütsel desteğin örgütsel sonuçlarına etkisine ilişkin ve kodlama stratejisi uygun verileri kapsayan 23 araştırma bu araştırmaya dâhil edilmiştir. Araştırma sonuçları, öğretmenlerin algıladığı örgütsel desteğin örgüt-iş uyumu sonuçlarını yüksek düzeyde ve pozitif yönde; davranışsal ve öznel iyi oluş sonuçlarını zayıf düzeyde ve pozitif yönde etkilediğini göstermiştir. Örneklem bölgesi ve öğretim kademesi değişkenleri öğretmenlerin algıladıkları örgütsel desteğin örgütsel sonuçları üzerindeki etkisinde moderatör değişkenler olarak anlamlı de ğildir.

\section{ARTICLE INFO}

\section{Keywords:}

Perceived Organizational

Support, Job Orientation

Toward The Organization

And Work, Behavioural

Outcomes, Subjective Well-

Being, Meta-Analysis

Article history:

Received 31 May 2019

Received in revised form 17

September 2019

Accepted 08 October 2019

\begin{abstract}
A B S T R A C T
The purpose of this research is to reveal the effect size of the research that indicates the effect of the teachers' perceived organizational support on organizational outcomes and is to investigate whether the effect size to be obtained differs according to the sample region and educational level moderator variables by meta-analysis method. 23 researches, having appropriate data related to the effects of teachers' perceived organizational support on organizational variables and coding strategy were included in this study. The findings showed that perceived organizational support has high positive effects on job orientation toward the organization and work, whereas it has low positive effects on behavioural outcomes. And also, perceived organizational support has low positive effects on subjective well-being. The study indicating that the sampling region and educational level have a moderator role on the effect of perceived organizational support on organizational variables is not supported.
\end{abstract}

\footnotetext{
a İletişim kurulacak yazar, Öğr. Gör. Dr., Akdeniz Üniversitesi, Eğitim Fakültesi, Eğitim Bilimleri Bölümü, Antalya, Türkiye. E-mail: gamzekasalak@gmail.com.ORCID:0000-0002-5084-0054
} 


\section{GİRIŞ}

İşgörenlerin çalıştıkları kurumdaki üyelerin onlara değer vermeleri ve mutluluklarını önemsemelerine ilişkin bir algılama tarzı (Eisenberger, Huntington, Hutchison \& Sowa, 1986), olarak görülen örgütsel destek kavramı işgörenlerin gösterdikleri üstün çabaların kurumları tarafindan olumlu değerlendirilmeleri; kurumlarına sağladıkları katkılar sonucunda işgörenlerin sosyal-duygusal ihtiyaçlarının karşılanmaları ve huzurlarıyla ilgilenmeleridir (Eisenberger, Fasolo \& LaMastro, 1990; Yoshimura, 2003; Zagenczyk, 2001). Özetle, işgören değerlerinin örgüt tarafından anlaşılmasıdır (Eisenberger, Aselage, Sucharski \& Jones, 2004). Örgütsel davranış kavramında olumlu bir algı olarak tanımlanan ve kuramsal temellerini sosyal değişim kuramı, karşılıklı ilişki kuramı, örgütsel destek kuramı, lider-üye değişimi kuramı ve erg kuramının oluşturduğu örgütsel destek kavramı 1980'li yıllardan beri ilgili araştırmalara konu olmakta ve kavramla ilgili çeşitli modeller geliştirilmektedir (Rhoades \& Eisenberger, 2002; Shore \& Tetrick, 1991).

Algılanan örgütsel desteğin etkilediği düşünülen çok sayıda değişken bulunmaktadır. $\mathrm{Bu}$ değişkenlerin başında i) örgüt-iş uyumu, ii) davranışsal ve iii) öznel iyi oluş sonuçları gelmektedir. Örgüt-iş uyumu sonuçları ile işe bağlılık, örgütsel bağlılık, örgütsel güven ve örgütsel özdeşleşme; davranışsal sonuçlar ile işten geri çekilme, örgütsel vatandaşlık ve proaktif iş davranışları ve öznel iyi oluş sonuçları ile de pozitif öznel iyi oluş ve negatif öznel iyi oluş değişkenleri vurgulanmaktadır (Kurtessis, Eisenberger, Ford, Buffardi, Stewart \& Adis, 2017).. Algılanan örgütsel destek ve örgütsel sonuçları arasındaki ilişkileri ele alan araştırmalar incelendiğinde, örgütsel desteğin örgütsel sonuçları üzerindeki etki düzeyleri ve ilişkilerin yönü tartışılan bir konudur. Birçok araştırmada söz konusu değişkenler arasındaki ilişkilerin korelasyon katsayılarında farklılık gözlenebilir. Dolayısıyla, eğitim kurumlarında algılanan örgütsel destek ve sonuçlarıyla ilgili çok sayıda çalışmaya ulaşılabilir olsa da ilgili araştırmaların bir bütün halinde değerlendirilememesi alanyazın için bir eksiklik olarak değerlendirilebilir. Araştırmaların maliyet, zaman, mekân gibi nedenlerle sınırlı alanlarda gerçekleştirilmesi araştırma sonuçlarını etkilemektedir. $\mathrm{Bu}$ nedenle alanyazında, benzer problemleri açıklamaya çalışan araştırmaların bulgularının sentezine ve yorumlanmasına ihtiyaç duyulmaktadır (Çoğaltay, Karadağ \& Öztekin, 2014). Konuyla ilgili büyük resmin ortaya çıkarılması ile ilgili araştırmaların son durumlarının ortaya konulmasının yanı sıra yeni araştırmalar için stratejik bir yön belirlenmesi açısından de alanyazına katkı sağlanabilir. Ayrıca, tüm bu araştırmaların sonuçları, ileride algıladıkları örgütsel destek üzerine yapılacak olan araştırmalar için eleştirel bir bakış açısı sunabilir. Araştırma sonuçlarının öğretmenlerin algılanan örgütsel desteğin örgütsel sonuçlar üzerindeki etki büyüklüklerinin ortaya çıkarılması açısından da önem taşıdığı düşünülmektedir. Algılanan örgütsel desteğin hangi örgütsel sonuçlar üzerinde etkili olduğu araştırılmasına ihtiyaç duyulabilir. Algılanan örgütsel desteğin örgütsel sonuçları üzerindeki etkisinin varlığının bilinmesi ile öğretmenlerin okullarına olan bağlılıkları, güvenleri, özdeşleşmeleri ve işlerine olan bağlılıkları olarak bilenen okul-iş uyumlarının gelişimlerine katkı sağlayabilir. Okullarından beklenen desteği algılayan öğretmenlerde işlerinden geri çekilme davranışlarında azalma, örgütsel vatandaşlık ve proaktif iş davranışlarında artış; öznel iyi oluş çıktılarında da pozitif öznel iyi oluşta artış ve negatif öznel iyi oluşta ta düşme gözlenebilir. Böylece algılanan örgütsel destek kavramının araştırmacılar ve uygulayıcılar tarafindan daha iyi anlaşılmasına katkı sağlayabilir. Söz konusu değişkenler arasındaki ilişki hakkında daha genellenebilir ve güvenilir çıkarımda bulunabilir. Alanyazın incelendiğinde öğretmenlerin algıladıkları örgütsel desteği meta analiz yöntemi ile inceleyen herhangi bir araştırmaya rastlanılmamıştır. Dolayısıyla eğitim bilimleri alanında meta-analiz yönteminin kullanılması açısından da önemli olduğu düşünülmektedir.

$\mathrm{Bu}$ araştırmada Türkiye'de öğretmenlerin algıladıkları örgütsel desteğin örgütsel sonuçları üzerindeki etkilerini incelemek amaçlanmıştır. $\mathrm{Bu}$ amaç doğrultusunda; i) öğretmenlerin algıladıkları örgütsel desteğin örgütsel sonuçları üzerindeki etkisini belirten araştırmaların etki büyüklükleri ve ii) elde edilen ortalama etki büyüklüklerinin örneklem bölgesi ve eğitim kademesi moderatör değişkenlerine göre farklılık gösterip göstermediği meta-analiz yöntemi ile incelenmiştir.

\section{KAVRAMSAL ÇERÇEE}

\subsection{Algılanan örgütsel destek ve örgüt-iş uyumu sonuçları arasındaki ilişki}

Örgüt-iş иyumu sonuçlarından işe bağlılık, işgörenin işiyle psikolojik olarak özdeşleşme inancıdır (Kanungo, 1982). İşgörenin algıladığı örgütsel destek yüksek olduğunda, işgören çalışma ortamlarını daha keyifli bulmakta, çalışmalarının daha fazla takdir edildiğini hissetmekte ve sonuçta işlerine daha fazla ilgi göstermektedir (Eisenberger \& Stinglhamber, 2011). Dolayısıyla, algılanan 
örgütsel desteğin işe bağlllık üzerinde pozitif yönde bir etkisinin olabileceği düşünülmektedir. İşgörenin örgütsel üyeliğini devam ettirme arzusu, örgütsel amaç ve değerlere ulaşma inancı ve örgüt adına çalışmak için istekli olması (Cooper \& Robertson, 1986) olarak tanımlanan örgütsel bă̆gllık kavramının oluşmasında algılanan örgütsel desteğin önemli bir değişken olduğuna yönelik araştırmalar mevcuttur (Shore \& Tetrick, 1991; Wayne, Shore \& Liden, 1997). Algılanan örgütsel destek daha çok duygusal bağlılıkla ilişkilidir (Rhoades, Eisenberger \& Armeli, 2001). İşgörenler kurumlarında değerli olduklarını algıladıklarında ve işgörenlerin kurumlarında saygınlık, onaylama ve üyelik gibi sosyo-duygusal ihtiyaçları karşılandığında örgütlerine olan duygusal yönde bağl1lıkları da artmaktadır (Rhoades \& Eisenberger, 2002; Silbert, 2005). Eisenberger ve diğerleri (1990), örgütün işgören katkılarını değerlendirdiği ve işgören refahlarıyla ilgilendiğini algıladığı zaman işgörenin çalıştı̆̆ geliştireceklerini belirtmişlerdir. Dolayısıyla algılanan örgütsel desteğin örgütsel güvenle ilişkisini inceleyen ilgili alanyazın incelendiğinde (Annamalai, Abdullah \& Alazidiyeen, 2010; Asgari, Silong, Ahmad \& Samah, 2008) ilgili değişkenin örgütsel güven üzerinde pozitif yönde bir etkisinin olabileceği düşünülmektedir. Örgütsel özdeşleşme işgörenin örgütsel başarı ve başarısızlığını kendi başarısı ya da başarısızlığ olarak alg1lamas1 (Ashforth \& Mael, 1989), kendilerini örgütün bir parçası gibi hissetmesi (Scott \& Lane, 2000) ve örgütün iyi ve kötü gününde örgütü ile dayanışma içinde olması (Mael \& Ashforth, 1995) şeklinde tanımlanmaktadır. İşgörenler kurumları tarafından kendilerine değer verildiğini ve önemsendiklerini algılayarak örgütsel destek düzeylerinin artmasıyla birlikte işgörenlerin kurumlarıyla özdeşleşmelerinin de artması beklenmektedir (Armeli, Eisenberger, Fasolo \& Lynch, 1998; Sluss, Klimchak \& Holmes, 2008). Kavramsal teoriler ve ilgili araştırma sonuçları doğrultusunda aşağıdaki hipotezler geliştirilmiştir.

$\mathbf{H}_{\mathbf{1}}=$ Öğretmenlerin algıladıkları örgütsel destek ile örgüt-iş uyumu sonuçları arasında pozitif yönlü bir ilişki vardır.

$\mathbf{H}_{1 \mathbf{a}}=$ Öğretmenlerin algıladıkları örgütsel destek ile işe bağlılık arasında pozitif yönlü bir ilişski vardır.

$\mathbf{H}_{\mathbf{1 b}}=$ Öğretmenlerin algıladıkları örgütsel destek ile örgütsel bağlılık arasında pozitif yönlü bir ilişki vardır.

$\mathbf{H}_{1 \mathbf{c}}=$ Öğretmenlerin algıladıkları örgütsel destek ile örgütsel güven arasında pozitif yönlü bir ilişki vardır.
$\mathrm{H}_{1 \mathrm{~d}}=$ Öğretmenlerin algıladıkları örgütsel destek ile örgütsel özdeşleşme arasında pozitif yönlü bir ilişki vardir.

\subsection{Algılanan örgütsel destek ve davranışsal sonuçlar arasındaki ilişki}

Araştırmanın bir başka değişkenini algılanan örgütsel desteğin davranışsal sonuçlarından biri olan örgütün etkili ve verimli bir şekilde işleyişine katkıda bulunan isteğe bağlı ve gönüllü işgören davranışları (Organ, 1988) olarak tanımlanan örgütsel vatandaşlık davranışı oluşturmaktadır. Destekleyici bir örgüt ikliminde görev yapan bir işgören, kurumun amaçlarına ulaşmasına daha fazla katkıda bulunacak özgecilik, sivil erdem, vicdanlılık, nezaket ve sportmenlik davranışlarını kapsayan vatandaşlık davranışlarını sergileyeceklerdir (Sezgin, 2005; Howes, Citera \& Cropanzano, 1995; Zagenczyk, 2001). Birçok çalışmada algılanan örgütsel destek ve örgütsel davranış arasında pozitif bir ilişki bulunmuştur (Kaufman, Stamper \& Tesluk, 2001; Piercy, Cravens, Lane \& Vorhies, 2006; Randall, Cropanzano, Bormann \& Birjulin, 1999). Yüksek algılanan örgütsel desteğe sahip işgörenlerde işten ayrılma niyeti, işe devamsızlık, işe geç kalma ya da işi yavaşlatma gibi davranışları içeren geri çekilme davranışları azalmaktadır (Çelik \& Turunç, 2010; Orthner \& Pittman, 1986; Shore \& Shore, 1995). Bununla birlikte sorumluluk ve insiyatif alma, görüş bildirme, yenilik geliştirme, değişime hazır olma ve problemleri engelleme davranışları gibi davranışları içeren proaktif davranışları da artmaktadır (Fay \& Frese, 2001; Parker \& Collins, 2010). Kavramsal teoriler ve ilgili araştırma sonuçları doğrultusunda aşağıdaki hipotezler geliştirilmiştir:

$\mathbf{H}_{2}=$ Öğretmenlerin algıladıkları örgütsel destek ile davranışsal sonuçları arasında pozitif yönlü bir ilişki vardır.

$\mathbf{H}_{2 \mathrm{a}}=$ Öğretmenlerin algıladıkları örgütsel destek ile işten geri çekilme davranışı arasında negatif yönlü bir ilișki vardır.

$\mathbf{H}_{\mathbf{2 b}}=$ Öğretmenlerin algıladıkları örgütsel destek ile örgütsel vatandaşlık arasında pozitif yönlü bir ilişki vardır.

$\mathbf{H}_{\mathbf{2 c}}=$ Öğretmenlerin algıladıkları örgütsel destek ile proaktif iş davranışları arasında pozitif yönlü bir ilişki vardır. 


\subsection{Algılanan örgütsel destek ve öznel iyi oluş sonuçları arasındaki ilişki}

Algılanan örgütsel desteğin etkilediği son değişken pozitif ve negatif öznel iyi oluş değişkenleridir. Öznel iyi oluş, işgörenlerin ruh hallerini, duygularını ve memnuniyet değerlendirmesini kapsayan bir kavramdır (Diener, Scollon \& Lucas, 2004). Algılanan örgütsel destek, işgörenin sosyoduygusal ihtiyaçları karşılamalı, işgören ihtiyaç duyduğunda yardım beklentisini arttırmal, işgörenin ödül beklentilerini ve öz yeterliliklerini güçlendirmelidir. Böylece iş tatmini, yaşam memnuniyeti ve pozitif psikolojik sermaye kavramlarını kapsayan pozitif öznel iyi oluşu artırmalıdır. Bunun yanı sıra, algılanan örgütsel destek iş stresi, iş tükenmişliği ve işyerindeki yalnızlığı azaltmak için önemli bir kaynak (Maslach, 1982) olarak hizmet etmelidir (Kurtessis vd., 2017). Kavramsal teoriler ve ilgili araştırma sonuçları doğrultusunda aşağıdaki hipotezler geliştirilmiştir:

$\mathbf{H}_{3}=$ Öğretmenlerin algıladıkları örgütsel destek ile öznel iyi oluş sonuçları arasında pozitif yönlü bir ilişki vardır.

$\mathbf{H}_{3 \mathrm{a}}=$ Öğretmenlerin algıladıkları örgütsel destek ile pozitif öznel iyi oluş arasında pozitif yönlü bir ilişki vardır.

$\mathbf{H}_{\mathbf{3 b}}=$ Öğretmenlerin algıladıkları örgütsel destek ile negatif öznel iyi oluş arasında pozitif yönlü bir ilişki vardır.

\section{YÖNTEM}

\subsection{Araştırmanın Deseni}

$\mathrm{Bu}$ araştırmada, öğretmenlerin algıladıkları örgütsel desteğin örgütsel sonuçları üzerindeki etkisini belirlemek amaciyla sistematik derleme yöntemlerinden meta analiz yöntemi kullanılmıştır. Meta-analiz yöntemi, belirli bir konudaki benzer araştırmaların nicel bulgularını tutarlı ve uyumlu bir şekilde toparlayan istatistiksel bir yöntemdir (Cohen, Manion \& Morrison, 2007). Böylece, bu araştırmada belirli bir konuda çeşitli araştırmalardan elde edilen nicel bulgular tutarlı ve uyumlu bir şekilde bileştirilerek genel bir sonuç elde etmek ve önemli moderatör değişkenleri ortaya koymak amaçlanmaktadır (Cohen, 1988; Dinçer, 2014; Radin \& Ferrari, 1991).

\subsection{Verilerin Toplanması ve Kodlanması}

Araştırmada meta-analize dâhil edilecek araştırmaları (makale ve tezler) tespit etmek için, örneklemin Türkiye sınırları kapsamında yer alması sebebiyle, Academic Search Complete, Business Source Complete, DOAJ, EBSCO, Emerald, ERIC, IEEE XploreDigital Library, JSTOR, PsycINFO, SageJournals Online, Science Direct, Springer Link, Taylor and Francis Online Journals, ULAKBİM, YÖK Tez Merkezi, Wiley Online Library, Web of Knowledge, Web of Science veri tabanlarında alanyazın taraması gerçekleştirilmiştir. Alanyazın tarama stratejisi olarak araştırmaların 2004-2018 yıllarında yapılması, korelasyonel meta-analiz için gerekli istatistikî bilgilerin bulunması, örneklemin Türkiye sınırları üzerinde gerçekleşmesi, örneklemin öğretmenlerden oluşması ve makalelerin hakemli dergilerde yayınlanması kriterleri belirlenmiştir. İlgili veri tabanlarında algılanan örgütsel destek konusu tarandığında örneklemin Türkiye ve öğretmenler üzerinde gerçekleşen ilk araştırmanın 2004 yılında gerçekleşmesi ve araştırmacın verileri taradığ tarihin son Aralık 2018 olması sebebiyle 2004-2018 yılları arasinda tarama stratejisinin gerçekleştirilmesi tercih edilmiştir.

Algılanan örgütsel destek ve örgütsel sonuçları arasındaki korelasyonel tarama modeli desenindeki araştırmalara ulaşmak için örgütsel destek (organizational support) ve algilanan örgütsel destek-AÖD (percived organizational support-POS) terimleri temel alınarak tarama işlemi gerçekleştirilmiş; örgütsel destek ve örgütsel sonuçları araştırmaların anahtar kelimeleri, başlıkları ve özetlerinde taranmıştır. Ayrıca, algılanan örgütsel desteğin etkilediği i) örgüt-iş иуити sonuçları işe bağlllık, örgütsel bağlllık, örgütsel güven ve örgütsel özdeşleşme, ii) davranışsal sonuçları işten geri çekilme, örgütsel vatandaşlık ve proaktif iş davranışları ve iii) öznel iyi oluş sonuçlart pozitif iyi oluş ve negatif iyi oluş terimleri temel alınarak ilgili kavramlar araştırmalarda incelenmiştir.

Meta-analize uygun olan araştırmaları belirlemek için öncelikle tüm öğretim kademesinde yer alan eğitim kurumlarındaki algılanan örgütsel destek ve örgütsel sonuçları ile ilişkili araştırmalardan oluşan bir çalışma havuzu (59 araştırma) elde edilmiştir. Çalışma havuzunda yer alan özetlerin incelenmesi sonucunda 32 araştırmada herhangi bir nicel verinin belirtilmemesi, korelasyon değerlerlerinin bulunmaması ve öğretmenlerin örgütsel destek algılarına değinilmemesi gibi nedenlerle araştırmalar kapsam dışı bırakılmıştır. Geriye kalan 27 araştırmanın derinlemesine incelenmesi sonucunda, bu araştırmaların 4'ünün tezden makale üretilmesi nedeniyle 23'ünün uygun olduğu belirlenmiştir. $\mathrm{Bu}$ araştırmada, algılanan örgütsel desteğin sonuçları i) örgüt-iş uyumu, ii) davranışsal ve iii) öznel iyi oluş sonuçları bağlamında ele 
Tablo 1: Öğretmenlerin örgütsel destek algıları ve örgütsel sonuçları ile ilgili meta-analize dâhil edilen araştırmalara ait betimleyici istatistikî bilgiler

\begin{tabular}{|c|c|c|c|c|c|c|c|c|}
\hline Değişkenler & & & & & & & & Toplam \\
\hline \multirow{3}{*}{$\begin{array}{c}\text { Araştırmanın } \\
\text { yayım yılı }\end{array}$} & & 2004-2013 & 2014 & 2015 & 2016 & 2017 & 2018 & \\
\hline & $\mathrm{n}$ & 5 & 2 & 4 & 2 & 4 & 6 & 23 \\
\hline & $\%$ & 21,73 & 8,69 & 17,39 & 8,69 & 17,39 & 26,08 & 100 \\
\hline \multirow{3}{*}{$\begin{array}{l}\text { Araştırmanın } \\
\text { yayım türü }\end{array}$} & & Tez & Makale & & & & & \\
\hline & $\mathrm{n}$ & 9 & 14 & & & & & 23 \\
\hline & $\%$ & 39,13 & 60,87 & & & & & 100 \\
\hline \multirow{3}{*}{$\begin{array}{l}\text { Örneklem } \\
\text { bölgesi }\end{array}$} & & Akdeniz & $\begin{array}{c}\text { Doğu } \\
\text { Anadolu }\end{array}$ & İç Anadolu & Karadeniz & Marmara & Belirtilmemiş & \\
\hline & $\mathrm{n}$ & 2 & 2 & 6 & 8 & 3 & 2 & 23 \\
\hline & $\%$ & 8,69 & 8,69 & 26,08 & 34,78 & 13,04 & 8,69 & \\
\hline \multirow{3}{*}{$\begin{array}{l}\text { Öğretim } \\
\text { kademesi }\end{array}$} & & Anaokulu & İlkokul & İlköğretim & Ortaöğretim & Karma & & \\
\hline & $\mathrm{n}$ & 1 & 3 & 5 & 8 & 6 & & 23 \\
\hline & $\%$ & 4,34 & 13,04 & 21,73 & 34,78 & 26,08 & & 100 \\
\hline
\end{tabular}

alındığı için mevcut 23 araştırmadaki örgütsel sonuçların çeşitliliğine dayalı olarak analizler 34 araştırma üzerinde gerçekleştirilmiştir (Tablo 1).

Araştırmada meta-analiz sürecine dâhil edilecek araştırmaları kodlamak için araştırmacı tarafindan bir kodlama formu geliştirilmiştir. Kodlama formunda (i); betimleyici istatistikî bilgiler (araştırmanın adı, yazar(lar)1, yayın yılı ve yayım türü, örneklem büyüklügüu, örneklem bölgesi ve öğretim kademesi) ve (ii) araştırma değişkenlerine ait istatistikî bilgiler (bağımlı değişkenler-algılanan örgütsel desteğin örgütsel sonuçları ve bağımsız değişken-algılanan örgütsel destek), bağımlı ve bağımsız değişkenleri ölçmek için kullanılan ölçekler, bağımlı ve bağımsız değişkenler arasındaki korelasyonel değerler) Excel programına kodlanmıştır. Böylece, meta analize dâhil edilen araştırmaların kalitesi kodlama aşamasında irdelenmeye çalışıllmıştır.

Meta-analize dâhil edilen araştırmalara ait betimleyici istatistikî bilgiler incelendiğinde ögretmenlerin örgütsel destek algılarının örgütsel sonuçları ile ilişkisine ilişskin 9'u tez ve 14'ü makaleden elde edilen verilerini kapsayan 22 araştırmanın; 5'i 2004-2013 yılları arsında, 2'si 2014, 4'ü 2015, 2'si 2016, 4'ü 2017 ve 6's1 2018 yıllarında gerçekleştirilmiştir. Tüm araştırmalarda 11225 öğretmen yer almaktadır. Karadeniz bölgesinde 8'er; İç Anadolu bölgesinde 6'şar; Marmara bölgesinde 3'er; Akdeniz, Doğu Anadolu ve Marmara bölgelerinde 2'şer araştırma gerçekleştirilmiştir. Öğretim kademesine ilişkin araştırmaların dağılımı ise Anaokulu 1, İlkokul 3, İlköğretim 5, Ortaöğretim 8 ve Karma 6 şeklindedir. Araştırma değişkenlerine ait istatistikî bilgiler incelendiğinde, öğretmenlerin algıladıkları örgütsel desteği sonuçları olan bağımlı değişkenler i) örgütiş uyumu ( $\mathrm{k}$ işe bağlllık $=2, \mathrm{k}$ örgütsel bağlllık $=5, \mathrm{k}$ örgütsel güven $=5$ ve $\left.\mathrm{k}_{\text {örgütsel özdeşleme }}=5\right)$, ii) davranışsal ( $\mathrm{k}_{\text {işten }}$ geri çekilme davranışı $=3, \mathrm{k}$ örgütsel vatandaşlık davranışı $=2 \mathrm{ve} \mathrm{k}$ proaktif iş davranışları $=5$ ) ve iii) öznel iyi oluş sonuçları ( $\mathrm{k}$ pozitif öznel iyi oluș $=4$ ve $\mathrm{k}$ negatif öznel iyi oluş $=3$ ) şeklindedir. Meta analize tabi tutulan araştırmalarda araştırmanın bağımsız değişkeni olan algılanan örgütsel destek değişkenini ölçmek için 6 farklı ölçüm aracı kullanılmıştır.

\subsection{Verilerin Analizi}

Kodlama formunda yer alan araştırmaların uygun kodlanıp kodlanmadığına ilişkin güvenirlik çalışması gerçekleştirilmiştir. Bunun için metaanaliz araştırmaları konularında deneyimli iki alan uzmanından, kodlama listesinde yer alan araştırmaların yüzde $12,5^{\prime}$ 'ine karşılık gelen ve kura yoluyla seçilen yaklaşık üç araştırmanın, araştırmacı tarafından oluşturulan kodlama listesine bağlı kalarak yeniden kodlamaları istenmiştir. Meta-analiz çalışmalarında kodlama formunun güvenirliğini belirlemede kullanılan ve kodlayıcılar aras1 güvenirliği tespit eden (Leary, 2012) Kohen Kappa tutarlılık katsayıları hesaplanmış; değer 0.89 $(\mathrm{p}<0.001)$ olarak tespit edilmiştir. Landis ve Koch' a göre (1977) elde edilen bu değerin kodlayıcılar arasında mükemmel bir uyum olduğunu göstermektedir.

$\mathrm{Bu}$ araştırmada meta-analiz sürecinin tümünde rassal etkiler modeli ve etki büyüklüğü hesaplanmasında iki değişkeni temel alan araştırmalar üzerinde karşılaştırılabilir olanaklar sunması nedeniyle Standartlaşstırlmış Ortalamaların Farkı (Hedges \& Olkin, 1985; Akt. 
Çoğaltay, Anar \& Karadağ, 2017) temel alınmıştır. Araştırmada, örneklem bölgesi ve öğretim kademesi değişkenleri ortalama etki büyüklüğünde rol oynayacağ1 düşünüldüğünden moderatör değişkenler olarak belirlenmiştir. Ayrıca, etki büyüklüğü değerleri i) $\mathrm{a}<0.10$ ise çok zayıf; $0.11<\mathrm{a}<0.30$ ise zayıf; $0.31<\mathrm{a}<0.50$ ise orta; $0.51<\mathrm{a}<0.80$ ise güçlü ve $\mathrm{a}>0.81$ ise çok güçlü düzeyde etki şeklinde sınıflandırılmıştır (Cohen vd., 2007).

\subsection{Yayım Yanlılığı}

Long'a (2001) göre, meta analiz araştırmalarında sadece anlamlı sonuçlar üreten yayınların araştırma sürecine dâhil edilmesi analiz sürecini olumsuz etkilemektedir. Dolayısıyla, meta analize başlamadan önce yayın yanlılığının incelenmesi önerilmektedir (Kalkan, 2017). Bu araştırmada yayın yanlılığı huni saçılım grafikleri, Duval ve Tweedie's Trim ve Fill Testleri, Begg ve Mazumdar sıra korelasyonları ve Klasik Güvenli N Analizi kullanılarak test edilmiştir. Yayın yanlılığının olasılığını gösteren huni saçılım grafiğinin sonuçları
Şekil 1, Şekil 2, Şekil 3 ve Şekil 4'de gösterilmektedir.

Her bir şekil incelendiğinde araştırmada yer alan çalışmaların çoğunluğu şeklin üst kısmında ve birleştirilmiş etki büyüklüğüne çok yakın bir konumda olduğu görülmektedir. Dolayısıyla bu araştırmaya dâhil edilen her bir araştırmanı yayın yanlılığına sahip olmadığı ifade edilebilir. Yayın yanlılığını belirlemek için hesaplanan Duval ve Tweedie's Trim ve Fill Testleri sonuçları Tablo 2'de yer almaktadır.

Tablo 2 incelendiğinde gözlenen değerler ile yayım yanlılığından kaynaklanabilecek etkiyi düzeltmek için belirtilen düzeltilmiş değerler arasından herhangi bir farkın olmadığı görülmektedir. Dolayısıyla, merkez çizgisinin her iki tarafinda herhangi bir kayıp verinin olmadığı ve her iki tarafında yoğunlaşan araştırmaların simetrik bir dağılım gösterdiği ifade edilmektedir (Çoğaltay vd., 2014).

Yayın yanlılığını belirlemek için bir önceki testlere

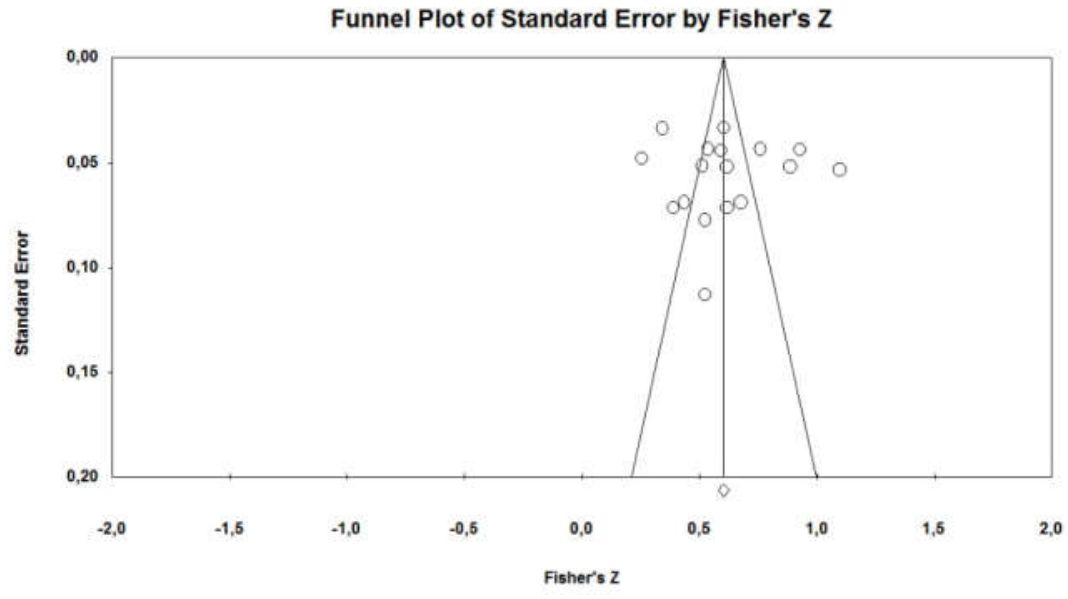

Şekil 1: Algılanan örgütsel destek ile örgüt-iş uyumu sonuçları ilişkisine ait huni saçılım grafiği

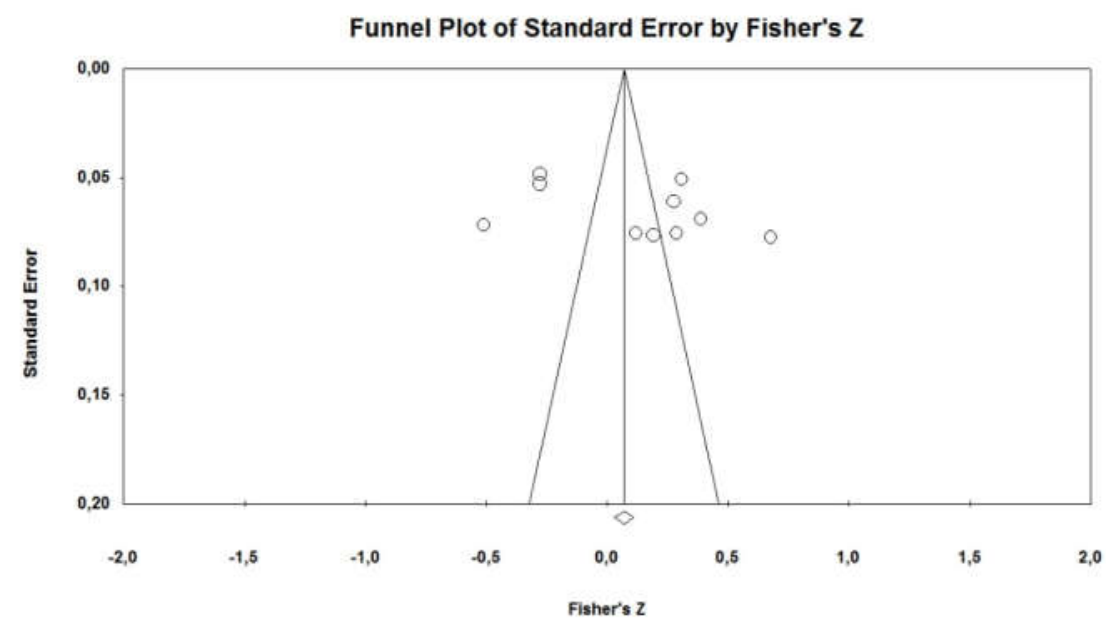

Şekil 2: Algılanan örgütsel destek ile davranışsal sonuçlar ilişkisine ait huni saçılım grafiği 


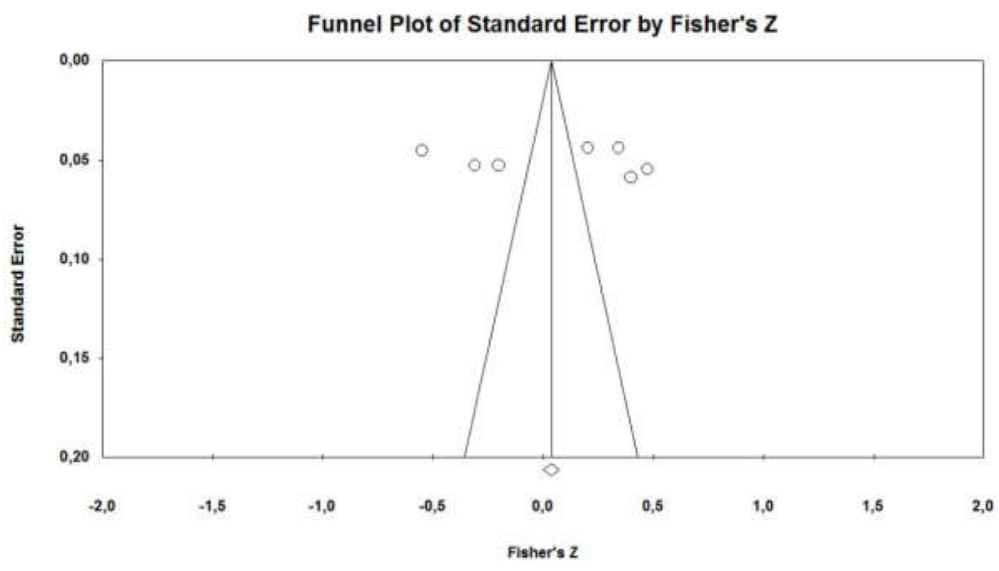

Şekil 3: Algılanan örgütsel destek ile öznel iyi oluş sonuçları ilişkisine ait huni saçılım grafiği

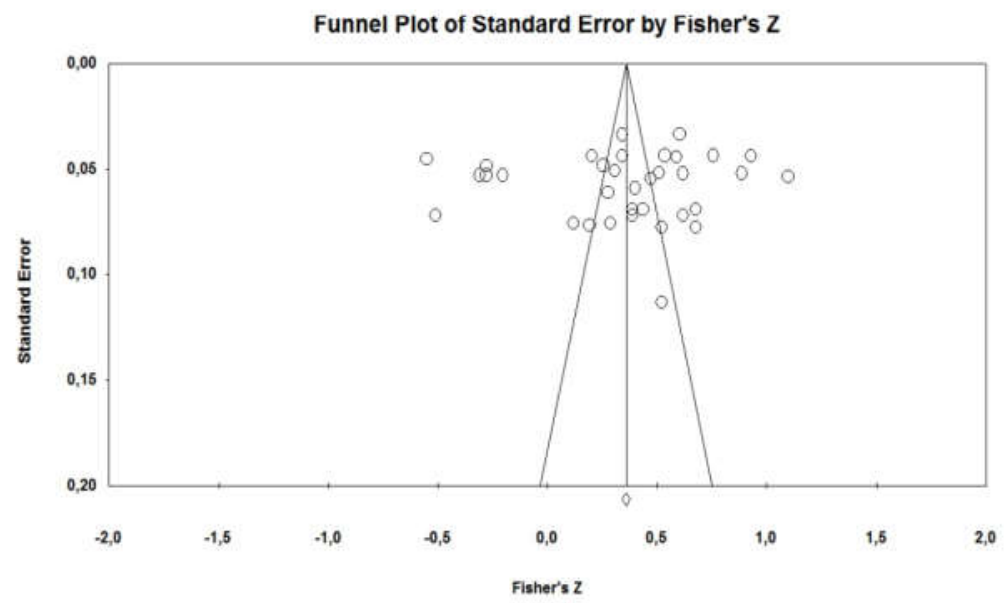

Șekil 4: Algılanan örgütsel destek ile tüm örgütsel sonuçlan ilișkisine ait huni saçılım grafiği

ek olarak Begg ve Mazumdar sira korelasyonlarında hesaplanan Kendall tau b katsayı değerleri Tablo 3'de yer almaktadir.
Tablo 3 incelendiğinde Kendall'in Tau katsayılarının iki uçlu $p$ değerinin istatistiksel olarak anlamlı bir fark yaratmaması beklenmektedir (Dinçer, 2014). Tüm değişkenler incelendiğinde iki

Tablo 2: Duval ve Tweedie's Trim ve Fill Testleri Sonuçları

\begin{tabular}{|c|c|c|c|c|c|}
\hline \multirow[b]{2}{*}{ Değişkenler } & \multirow[b]{2}{*}{$\begin{array}{l}\text { Çıkartılmış } \\
\text { Çalışma (sağ) }\end{array}$} & \multirow[b]{2}{*}{ Nokta Tahmini } & \multicolumn{2}{|c|}{ CI (Güven Aralığı) } & \multirow[b]{2}{*}{$\mathbf{Q}$} \\
\hline & & & Alt Limit & Üst Limit & \\
\hline \multicolumn{6}{|c|}{ AÖD-Örgüt-iş иуuтu sonuçları } \\
\hline Gözlenen değerler & & $.54^{*}$ & .46 & .61 & 317.65 \\
\hline Düzeltilmiş değerler & 0 & $.54 *$ & .46 & .61 & 317.65 \\
\hline \multicolumn{6}{|c|}{ AÖD-Davranışsal sonuçlar } \\
\hline Gözlenen değerler & & $.11 *$ & -.10 & .32 & 286.65 \\
\hline Düzeltilmiş değerler & 0 & $.11 *$ & -.10 & .32 & 286.65 \\
\hline \multicolumn{6}{|c|}{ AÖD-Öznel iyi oluş sonuçları } \\
\hline Gözlenen değerler & & $.05^{*}$ & -.24 & .33 & 395.47 \\
\hline Düzeltilmiş değerler & 0 & $.05^{*}$ & -.24 & .33 & 395.47 \\
\hline \multicolumn{6}{|l|}{ AÖD-Tüm sonuçlar } \\
\hline Gözlenen değerler & & $.33 *$ & ,20 & 45 & 1915.13 \\
\hline Düzeltilmiş değerler & 0 & $.33^{*}$ & ,20 & 45 & 1915.13 \\
\hline
\end{tabular}


Tablo 3: Begg ve Mazumdar sıra korelasyonlarına ait Kendall'ın Tau b katsayı değerleri

\begin{tabular}{lcccc}
\hline Değişkenler & Tau & Tau'nun Z değeri & P değeri (1 uçlu) & P değeri (2 uçlu) \\
\hline AÖD-Örgüt-iş uyumu sonuçlart & & & & \\
\hline &, 00 &, 00 & 5 & 1 \\
\hline AÖD-Davranışsal sonuçlar & & & &, 53 \\
\hline &, 15 &, 62 &, 38 &, 76 \\
\hline AÖD-Öznel iyi oluş sonuçlarl & & & & \\
\hline &, 09 &, 30 & 0,53 \\
\hline AÖD-Tüm sonuçlar & & & 0,26 & \\
\hline
\end{tabular}

Tablo 4: Klasik Güvenli N Analizi

\begin{tabular}{lccc}
\hline Değişkenler & P değeri & Alfa değeri & $\begin{array}{c}\text { p>alpha } \\
\text { için gerekli } \\
\text { çalışma sayısı }\end{array}$ \\
\hline $\begin{array}{r}\text { AÖD-Örgüt-iş uyumu sonuçları }(N=17) \\
48,10\end{array}$ & 0,00 & 0,05 & 225 \\
\hline AÖD-Davranışsal sonuçlar $(N=10)$ & & & 48 \\
\hline 4,68 & 0,00 & 0,05 & 3 \\
\hline AÖD-Öznel iyi oluş sonuçlarl $(N=7)$ & & & \\
\hline AÖD-Tüm sonuçlar $(N=34)$ & 0,02 & 0,05 & 2466 \\
\hline
\end{tabular}

uçlu p değerinin 005 ’ten büyük olması nedeniyle, meta analize dâhil edilen araştırmalarda yayın yanlılığının olmadığından bahsedilebilir.

Yayın yanlılığı ve meta-analizin gücünü belirlemek için hesaplanan klasik güvenli N Analizi sonuçları Tablo 4'de yer almaktadır.

Tablo 4 incelendiğinde, Klasik Güvenli N analizindeki $p$ değerinin alfa değerinden küçük olması çalışmanın güçlü ve güvenilir olduğunun göstermektedir (Dağyar \& Demirel, 2015). Ayrıca meta-analiz çalışmasının sonucunun geçersiz olması için toplamda 2466; örgüt iş uyumu sonuçları için 225 , davranışsal sonuçları için 48 ve öznel iyi oluş sonuçları için de 6 tane bireysel araştırmanın daha analize eklenmesi gerekmektedir.

Huni grafiklerinin simetrik olmas1, Duval ve Tweedie's Trim ve Fill Testlerinde düzeltimiş değerlerin olmaması, Kendal tau b değerlerinin anlamsız olması ve Klasik Güvenli N Analizinde $p$ değerlerinin alfa değerlerinden küçük olması bu meta-analiz araştırmasında yayın yanlılığının olmadığını göstermektedir.

\section{BULGULAR}

\subsection{Algılanan örgütsel destek ve örgüt-iş uyumu sonuçlarına ilișin bulgular}

Tablo 5'te algılanan örgütsel destek ve örgüt-iş иуити sonuçları arasındaki meta-analiz sonuçları sunulmuştur. Bulgular, algılanan örgütsel desteğin örgüt-iş uyumu sonuçlarından İşe bağl1lık $[\mathrm{r}=.36]$ ve örgütsel özdeşleşme $[\mathrm{r}=.44]$ üzerinde orta düzeyde; örgütsel güven $[\mathrm{r}=.60]$ ve örgütsel bağl1lık $[\mathrm{r}=$.62] üzerinde yüksek düzeyde (Cohen vd., 2007) bir ortalama etki büyüklüğüne sahip olduğunu göstermektedir. Algılanan örgütsel desteğin örgüt-iş uyumu sonuçları üzerinde en yüksek düzeyde etkisi örgütsel bağlılık üzerineyken; en düşük düzeyde etkisi de işe bağlılık üzerindedir. Ayrıca, algılanan örgütsel desteğin toplam örgüt-iş uyumu sonuçları üzerindeki ortalama etki büyüklüğü değeri .54 olarak belirlenirken alt sınır değeri .47 , üst sınır değeri ise .60 olarak hesaplanmıştır. $\mathrm{Bu}$ değer, algılanan örgütsel desteğin örgüt -iş uyumu sonuçları üzerinde yüksek düzeyde (Cohen vd., 2007) bir ortalama etki büyüklüğüne sahip olduğunu göstermektedir. 
Tablo 5: Algılanan örgütsel destek ile örgüt-iş uyumu sonuçları ilişkisine ait meta-analiz sonuçları

\begin{tabular}{|c|c|c|c|c|c|c|}
\hline \multirow{2}{*}{ Değişkenler } & \multirow{2}{*}{$\boldsymbol{k}$} & \multirow{2}{*}{$N$} & \multirow[b]{2}{*}{$\boldsymbol{r}$} & \multicolumn{2}{|c|}{ CI (Güven Aralığı) } & \multirow[t]{2}{*}{$Q$} \\
\hline & & & & Alt Limit & Üst Limit & \\
\hline İşe Bağlılık & 2 & 811 & 0,36 & 0,13 & 0,55 & $12,99^{*}$ \\
\hline Örgütsel Bağlılık & 5 & 2521 & 0,62 & 0,51 & 0,70 & $62,10^{*}$ \\
\hline Örgütsel Güven & 5 & 1803 & 0,60 & 0,45 & 0,72 & $76,82 *$ \\
\hline Örgütsel Özdeşleşme & 5 & 1697 & 0,44 & 0,33 & 0,53 & $22,15^{*}$ \\
\hline Toplam & 17 & 6832 & 0,54 & 0,47 & 0,60 & $8,223 *$ \\
\hline
\end{tabular}

Tablo 6: Algılanan örgütsel destek ile davranışsal sonuçları ilişkisine ait meta-analiz sonuçları

\begin{tabular}{|c|c|c|c|c|c|c|}
\hline \multirow{2}{*}{ Değişkenler } & \multirow{2}{*}{$\mathbf{k}$} & \multirow{2}{*}{$\mathbf{N}$} & \multirow{2}{*}{$\mathbf{r}$} & \multicolumn{2}{|c|}{ CI (Güven Aralığı) } & \multirow[t]{2}{*}{$\mathbf{Q}$} \\
\hline & & & & Alt Limit & Üst Limit & \\
\hline İşten geri çekilme davranışı & 3 & 985 & $-0,33$ & $-0,44$ & $-0,21$ & $8,45^{*}$ \\
\hline Örgütsel vatandaşlık davranışı & 2 & 381 & 0,48 & 0,24 & 0,67 & $7,74 *$ \\
\hline Proaktif iş davranışları & 5 & 1187 & 0,24 & 0,18 & 0,30 & 5,27 \\
\hline Toplam & 10 & 2553 & 0,10 & 0,03 & 0,17 & $84,45^{*}$ \\
\hline
\end{tabular}

\subsection{Algılanan örgütsel destek ve davranışsal sonuçlarına ilişin bulgular}

Tablo 6'da algılanan örgütsel destek ve davranışsal sonuçları arasındaki meta-analiz sonuçları sunulmuştur. Bulgular, algılanan örgütsel desteğin davranışsal sonuçlarından işten geri çekilme davranış1 [ $\mathrm{r}=-.33$ ] ve örgütsel vatandaşlık davranışı $[\mathrm{r}=.48]$ üzerinde orta düzeyde (Cohen vd., 2007) bir ortalama etki büyüklüğünün var olduğunu göstermektedir. İstatiksel anlamlılık açısından; algılanan örgütsel desteğin davranışsal sonuçları üzerinde en yüksek düzeyde etkisi örgütsel vatandaşlık davranışı üzerineyken; en düşük düzeyde etkisi de işten geri çekilme davranışı üzerindedir. Ayrıca, algılanan örgütsel desteğin davranışsal sonuçları üzerindeki ortalama etki büyüklüğü değeri .10 olarak belirlenirken; alt sınır değeri .03 ve üst sınır değeri ise .17 olarak hesaplanmıştır. $\mathrm{Bu}$ değer algılanan örgütsel desteğin davranışsal sonuçları üzerinde zaylf düzeyde (Cohen vd., 2007) bir ortalama etki büyüklüğü var olduğunu göstermektedir.

\subsection{Algılanan örgütsel destek ve öznel iyi oluş sonuçlarına ilişin bulgular}

Tablo 7'de algllanan örgütsel destek ve öznel iyi oluş sonuçları arasındaki meta-analiz sonuçları sunulmuştur. Bulgular, algılanan örgütsel desteğin öznel iyi oluş sonuçlarından pozitif öznel iyi oluş üzerinde pozitif ve negatif öznel iyi oluş üzerinde negatif etkisi olduğuna yönelik geliştirilen hipotezlerini desteklemektedir. Algılanan örgütsel destek pozitif öznel iyi oluş $[\mathrm{r}=.33]$ ve negatif öznel iyi oluş $[\mathrm{r}=-.34]$ üzerinde orta düzeyde (Cohen vd., 2007) bir ortalama etki büyüklüğüne sahiptir. Ayrıca, algılanan örgütsel desteğin tüm öznel iyi oluş sonuçları üzerindeki ortalama etki büyüklüğü değeri .04 olarak belirkenirken; alt sınır değeri -.06 ve üst sınır değeri ise .15 olarak hesaplanmıştır. $\mathrm{Bu}$ değer algılanan örgütsel desteğin tüm öznel iyi oluş sonuçları üzerinde zayıf düzeyde (Cohen vd., 2007) bir ortalama etki büyüklüğüne sahip olduğunu göstermektedir.

\subsection{Algılanan örgütsel destek ve tüm örgütsel sonuçlara ait moderatör analizi bulguları}

Tablo 8'de algllanan örgütsel destek ve örgütsel sonuçları arasındaki meta-analiz sonuçları yer almaktadır. Rassal etkiler modeline göre Türkiye örnekleminde öğretmenlerin algıladıkları örgütsel desteğin algıladıkları örgütsel sonuçları üzerindeki etki değeri .33 olarak hesaplanmış; etki değerinin orta düzeyde olduğu belirlenmiştir.

Öğretim kademesinin, algılanan örgütsel desteğin tüm örgütsel sonuçları arasındaki ilişkide moderatör değişkenin rolünü inceleyen moderatör analizinde, ortalama etki büyüklükleri fark1 istatistiksel olarak anlamlı görülmemektedir $\left(\mathrm{Q}_{\mathrm{b}}=1.142, \mathrm{p}>.05\right)$. Etki fark1 istatistiksel olarak anlamlı olmamasına rağmen; anaokulunda $[\mathrm{r}=.53]$ algılanan örgütsel desteğin örgütsel sonuçlar üzerindeki etkisi güçlüyken; lise [ $\mathrm{r}=.33$ ] ve karma $[\mathrm{r}=.38$ ] öğrenim kademelerindeki etki orta; ilkokul $[\mathrm{r}=.27]$ ve ilköğretim $[\mathrm{r}=.28]$ öğrenim kademelerindeki etki de zayıftır. 
Tablo 7: Algılanan örgütsel destek ile öznel iyi oluş sonuçlanı ilişkisine ait meta-analiz sonuçları

\begin{tabular}{|c|c|c|c|c|c|c|}
\hline \multirow{2}{*}{ Değiş̧kenler } & \multirow{2}{*}{$\mathbf{k}$} & \multirow{2}{*}{$\mathbf{N}$} & \multirow{2}{*}{$\mathbf{r}$} & \multicolumn{2}{|c|}{ CI (Güven Aralığı) } & \multirow[t]{2}{*}{$\mathbf{Q}$} \\
\hline & & & & Alt Limit & Üst Limit & \\
\hline Pozitif öznel iyi oluş & 4 & 1667 & 0,33 & 0,23 & 0,43 & $16,58^{*}$ \\
\hline Negatif öznel iyi oluş & 3 & 1213 & $-0,34$ & $-0,51$ & $-0,14$ & $27,01 *$ \\
\hline Toplam & 7 & 2880 & 0,04 & $-0,06$ & 0,15 & $39,50 *$ \\
\hline
\end{tabular}

Tablo 8: Algılanan örgütsel destek ve tüm örgütsel sonuçlara ait moderatör analizi sonuçları

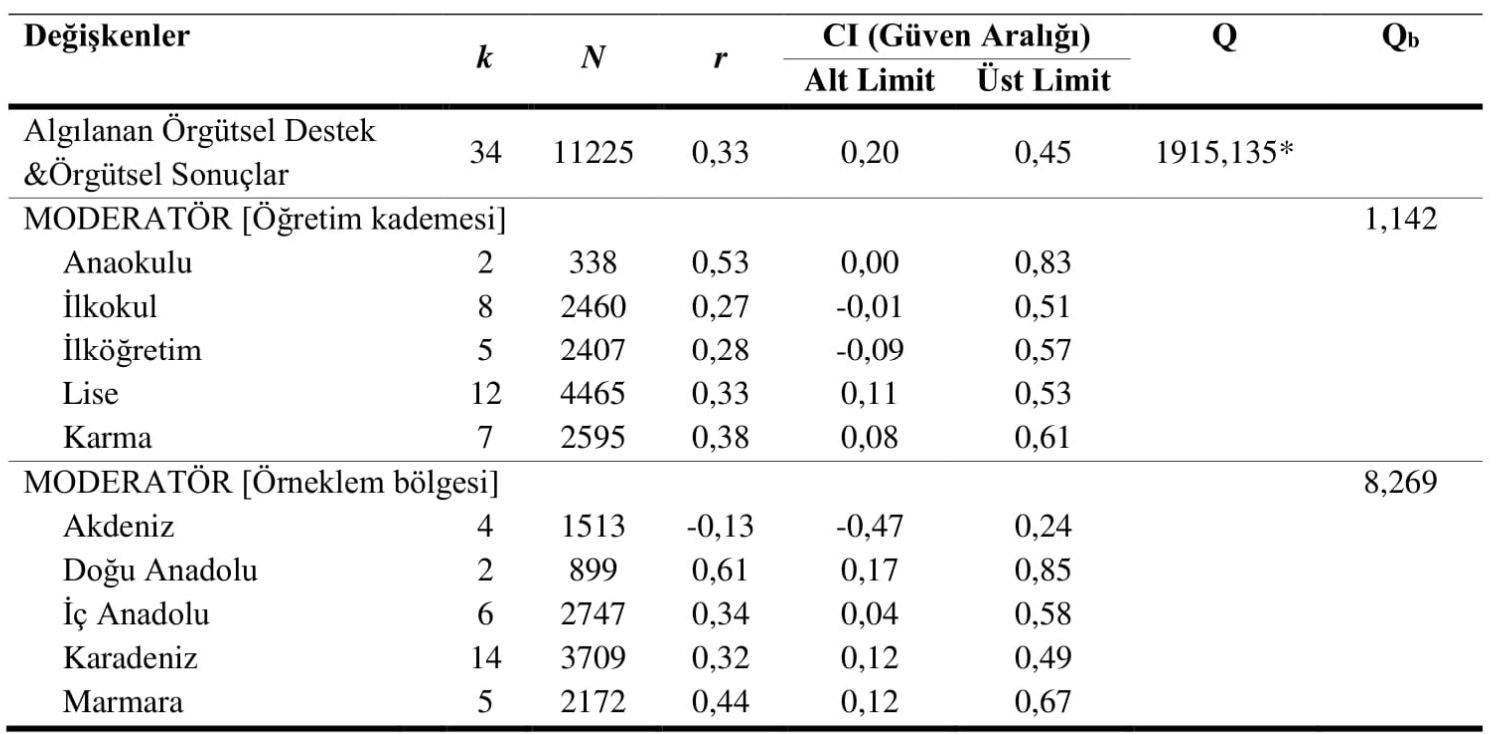

Örneklem bölgesinin, algılanan örgütsel destek ve örgütsel sonuçları arasındaki ilişkide moderatör değişkenin rolünü inceleyen moderatör analizinde, ortalama etki büyüklükleri fark1 istatistiksel olarak anlamlı görülmemektedir $\left(\mathrm{Q}_{\mathrm{b}}=8.269, \mathrm{p}>.05\right)$. İstatiki olarak anlamlı olmamasına rağmen etki büyükleri incelendiğinde; Doğu Anadolu [r =.61] bölgesinde algılanan örgütsel desteğin örgütsel sonuçlar üzerinde yüksek; Marmara $[\mathrm{r}=.44]$, İç Anadolu $[\mathrm{r}=.34]$ ve Karadeniz $[\mathrm{r}=.32]$ bölgelerinde algılanan örgütsel desteğin örgütsel sonuçlar üzerinde orta ve Akdeniz $[\mathrm{r}=-.13]$ bölgesinde zayıf düzeyde bir etkiye sahip olduğu görülmektedir.

\section{SONUÇ VE TARTIŞMA}

$\mathrm{Bu}$ araştırmada, öğretmenlerin algıladığı örgütsel desteğin örgütsel sonuçlar üzerindeki etkisi incelenmektedir. Meta-analiz sonuçları, öğretmenlerin algıladıkları örgütsel desteğin örgütsel sonuçları üzerinde orta düzeyde pozitif etkisi olduğunu göstermektedir. Kurtessis ve diğerleri (2017) algılanan örgütsel desteğin örgütsel sonuçlar i) örgüt-iş uyumu, ii) davranışsal ve iii) öznel iyi oluş sonuçları olmak üzere üç farklı şekilde sınıflandırmaktadır. Örgüt-iş uyumu sonuçları işe bağl1lık, örgütsel bağlılık, örgütsel güven ve örgütsel özdeşleşme; davranışsal sonuçlar işten geri çekilme davranış1, örgütsel vatandaşlık davranışı ve proaktif iş davranışlarını ve öznel iyi oluş sonuçları da pozitif öznel iyi oluş ve negatif öznel iyi oluş değişkenlerini içermektedir. Bu araştırmada da Kurtessis ve diğerlerinin (2017) sinıflandırması dâhilinde analizler geçekleştirilmiştir.

Öğretmenlerin algıladıkları örgütsel destek örgüt-iş иyити sonuçlarını yüksek düzeyde ve pozitif yönde etkilemektedir. Örgüt-iş uyumu sonuçları tek tek incelendiğinde; algılanan örgütsel desteğin örgütsel bağl1l1k ve örgütsel güveni yüksek düzeyde ve pozitif yönde, örgütsel özdeşleşme ve İşe Bağlılıkyi de orta düzeyde pozitif yönde etkilemektedir. Buna göre; öğretmenlerin kurumlarından algıladıkları örgütsel destek düzeyi artıkça kurumlarına duydukları bağlılık ve güven yüksek; kurumlarıyla özdeşleşmeleri ve işleriyle olan bütünleşmeleri de orta düzeyde artacağından bahsedilebilir. Algılanan örgütsel desteğin örgütsel bağl1lık (Arshadi, 2011; 
Aube, Rousseau \& Morin, 2007; Panaccio \& Vandenberghe, 2009; Rhoades vd., 2001), örgütsel güven (Duffy \& Lilly, 2013; Ng, 2015), örgütsel özdeşleşme (Edwards \& Peccei, 2010; Kurtessis vd., 2017; Sluss vd., 2008) ve İşe Bağlılık (Kurtessis vd., 2017; Wickramasinghe \& Wickramasinghe, 2011) üzerindeki pozitif etkisinin olduğu alanyazın tarafindan da desteklenmektedir. Örgütsel desteği yüksek düzeyde algılayan işgörenler, kurumları tarafından önemsendiği, iyi olmalarının düşünüldüğü, kendilerine değer verildiği ve her türlü konuda desteklendiklerine yönelik olumlu bir bakış açısı olmaları nedeniyle, kurumlarına olan bağlanma düzeylerinin yüksek düzeyde olması beklenmektedir (Eisenberger vd., 1986). Ayrıca, örgütsel destek algısının yüksekliği işgörenlerde kurumlarıyla daha fazla özdeşleşmeye ve işlerine olan bağlılıklarına da katkı sağlamaktadır (Kurtessis vd., 2017). Bununla birlikte, güvenli bir çalıșma ortamı sunduğu için; öğretim kalitesi ve okula uyumla ilişkili okul etkililiğine de katkı sağlamaktadır (Hoy, Tarter \& Witkoskie, 1992; Tarter, Bliss \& Hoy, 1989).

Öğretmenlerin algıladıkları örgütsel destek davranışsal sonuçlarını zayıf düzeyde ve pozitif yönde etkilemektedir. Davranışsal sonuçlar tek tek incelendiğinde; algılanan örgütsel desteğin örgütsel vatandaşlık davranışını orta düzeyde ve pozitif yönde; işten geri çekilme davranışını orta düzeyde ve negatif yönde etkilediği sonucu bulunmuştur. Buna göre; öğretmenlerin kurumlarından algıladıkları örgütsel destek düzeyi artıkça örgütsel vatandaşlık davranışları orta ve işten geri çekilme davranışları da orta düzeyde azalacağından bahsedilebilir. Algılanan örgütsel desteğin örgütsel vatandaşlık (Abed \& Elewa, 2016; Ahmed, Nawaz, Ali \& Islam, 2015; Jebeli \& Etebarian, 2015; Wayne vd., 1997) üzerindeki pozitif ve işten geri çekilme davranışı (Eder \& Eisenberger, 2008; Kurtessis vd., 2017) üzerindeki negatif etkisinin olduğu alanyazın tarafından da desteklenmektedir. İşgörenlerin yönetici ve çalıştığı kurumdan gördüğü olumlu davranışlar, onların benzer şekilde karşılık verme yönünde bir yükümlülük hissi oluşturmaktadır (Erdaş, 2010). Wayne ve Green'e (1993) göre, işgörenler çalıştıkların kurumun her koşulda yanlarında olduğunu ve kendilerine değer verildiğini hissettiklerinde bu duruma karşılık vermek için kurumlarına fayda sağlayacak davranışları tercih etmektedirler. Dolayısıyla işgörenlerin algıladıkları örgütsel desteğin yüksekliği örgütsel vatandaşlık düzeylerini artırması beklenmektedir. Dipaola ve Hoy'a göre (2005), örgütsel vatandaşlık düzeyleri yüksek olan öğretmenler, güç ve yeteneklerini öğrenciler ve okulun amaçlarına ulaşmasına harcayarak etkili eğitim-öğretim ortamı oluşturmaktadırlar. Ayrıca, algılanan örgütsel desteği yüksek işgörenler kurumlarıyla daha fazla özdeşleștiklerinden, kurumsal amaç ve hedefleri destekleme zorunluluğu hissettiklerinden, kurumlarından geri çekilmeye daha az eğilimli olmaları olası bir durumdur (Kurtessis vd., 2017).

$\mathrm{Bu}$ araştırmada elde edilen meta-analiz sonuçlarına göre öğretmenlerin algıladıkları örgütsel destek öznel iyi oluş sonuçlarını zayıf düzeyde ve pozitif yönde etkilemektedir. Öznel iyi oluş sonuçlar tek tek incelendiğinde; algılanan örgütsel desteğin pozitif öznel iyi oluşu orta düzeyde ve pozitif yönde; negatif öznel iyi oluşu da orta düzeyde negatif yönde etkilediği sonucu bulunmuştur. Buna göre; öğretmenlerin kurumlarından algıladıkları örgütsel destek düzeyi artıkça pozitif öznel iyi oluş düzeylerinin orta düzeyde artacağından; negatif öznel iyi oluş düzeylerinin de orta düzeyde azalacağından bahsedilebilir. Algılanan örgütsel desteğin örgütsel pozitif öznel iyi oluş üzerindeki pozitif (Zhai, Wang \& Weadon, 2017) ve negatif öznel iyi oluş (Jawahar, Stone \& Kisamore, 2007; Walters \& Raybould, 2007) üzerindeki negatif etkisinin olduğu alanyazın tarafindan da desteklenmektedir (Kurtessis vd., 2017).

Algılanan örgütsel desteğin tüm örgütsel sonuçları arasındaki ilişkide ögretim kademesi ve örneklem bölgesi moderatör değişkenlerinin etki düzeyleri fark1 istatistiksel olarak anlamlı değildir. Bir başka değişle örneklem bölgesi ve öğretim kademesi değişkenleri öğretmenlerin algıladıkları örgütsel desteğin örgütsel sonuçları üzerindeki etkisinde moderatör değişkenler olarak anlamlı değildir. Dolaysıyla öğretmenlerin görev yaptıkları örneklem bölgesi ve öğretim kademelerinin algıladıkları örgütsel desteğin örgütsel sonuçları üzerindeki etkisinde herhangi bir rolünün olmadığından bahsedilebilir. Son olarak, moderatör değişkeni bulgularına göre, algılanan örgütsel desteğin tüm örgütsel sonuçlara olan etkisi pozitif yönde ve orta düzeydedir.

Araştırma sonuçları, ilgili konuyla ilgili nicel verilerin araştırma sonuçlarına göre algılanan örgütsel desteğin örgüt-iş uyumu, davranışsal ve öznel iyi oluş gibi örgütsel sonuçlart etkilemesi açısından önemlidir. Dolayısıyla, öğretmenlerin algıladıkları örgütsel destek düzeylerinin örgütsel sonuçlar üzerindeki yordayıcı etkilerinin derinlemesine incelenmesi adına nitel araştırmaların gerçekleştirilmesi önerilebilir. Algılanan örgütsel desteğin örgütsel sonuçlar üzerindeki orta düzeyde pozitif etkisinden hareketle, öğretmenlerin örgütsel destek algılarını yükseltmeye yönelik okullarda gerekli uygulamalar yapılıp gerekli tedbirler alınmalıdır. Bu araştırma öğretmenlerin algıladıkları örgütsel desteğin örgütsel sonuçlara etkisini belirlemeye yönelik gerçekleştirilmiş olup; bir 
sonraki araştırmalarda, algılanan örgütsel destek ve örgütsel öncülleri arasındaki ilişkilere yönelik korelasyonel meta-analiz çalışmaları düzenlenebilir. $\mathrm{Bu}$ araştırmanın örneklemi öğretmenlerden oluşmakta olup; okul yöneticilerinin yer aldı̆̆ örneklemin yer aldığ 1 bir başka meta analiz çalışması gerçekleşebilir. Meta-analize dâhil edilen ilgili araştırmalar anaokulu, ilkokul, ortaokul ve lise düzeyinde gerçekleştirilmiştir. Gelecekteki araştırmalar, yükseköğretim düzeyinde yapılan olan araştırmaların dâhil edilmesiyle tekrarlanabilir.

\section{ETIKK BEYANATI}

Destek Bilgisi: Bu çalıșma, kamu, ticari veya kar amacı gütmeyen kuruluşlar gibi herhangi bir organizasyondan destek almamıştır.

Çıkar Çatışması: Sorumlu yazar, çıkar çatışması olmadığını belirtmektedir.

Etik Onayı: İnsan katılımcıları içeren çalışmalarda gerçekleştirilen tüm prosedürler, kurumsal ve / veya ulusal araştırma komitesinin etik standartlarına ve 1964 Helsinki deklarasyonuna ve daha sonraki değişikliklerine veya karşılaştırılabilir etik standartlara uygundur.

\section{KAYNAKÇA}

Abed, F. \& Elewa, A. H. (2016). The Relationship between organizational support, work engagement and organizational citizenship behavior as perceived by staff nurses at different hospitals. IOSR Journal of Nursing and Health Science (IOSR-JNHS), 5(4), 113123.

Ahmed, I., Nawaz, M. M., Ali, G. \& Islam, T. (2015). Perceived organizational support and its outcomes: A meta-analysis of latest available literature, Management Research Review, 38(6), 627-639, https://doi.org/10.1108/MRR-09-2013-0220

Annamalai T., Abdullah A. G. K. \& Alazidiyeen N. J. (2010). The mediating effects of perceived organizational support on the relationships between organizational justice, trust and performance appraisal in Malaysian secondary schools, European Journal of Social Sciences, 13(4), 623-632.

Armeli, S., Eisenberger, R., Fasolo, P. \& Lynch, P. (1998). Perceived organizational support and police performance: The moderating influence of socioemotional needs. Journal of Applied Psychology, 83(2), 288-297. http://dx.doi.org/10.1037/0021-9010.83.2.288

Arshadi, N. (2011). The relationships of perceived organizational support (POS) with organizational commitment, in-role performance, and turnover intention: Mediating role of felt obligation. Procedia Social and Behavioral Sciences, 30, $1103-1108$

Ashforth, B. E. \& Mael, F. (1989). Social identity theory and the organization. The Academy of Management Review, 14(1), 20-39. $\mathrm{http} / / / \mathrm{dx}$. doi.org/10.2307/258189

Asgari, A., Silong, A. D., Ahmad A. \& Samah B. A. (2008). The Relationship between transformational leadership behaviors, organizational justice, leadermember exchange, perceived organizational support, trust in management and organizational citizenship behaviors, European Journal of Scientific Research, 23(2), 227-242.

Aube, C., Rousseau, V. \& Morin, E. M. (2007). Perceived organizational support and organizational commitment: The moderating effect of locus of control and work autonomy. Journal of Managerial Psychology, 22(5), 479-495. http://dx.doi.org/10.1108/02683940710757209.

Cohen, J. (1988). Statistical power analysis for the behavioral sciences. Hillside, NJ: Lawrence Erlbaum Associates.

Cohen, L., Manion, L. \& Morrison, K. (2007). Research methods in education (6th ed.). New York, NY, US: Routledge/Taylor \& Francis Group. 
Cooper, C. L. \& Robertson, I. T. (1986). The international review of industrial and organizational psychology. Chichester and NewYork: John Wiley\&Sons.

Çoğaltay, N., Karadağ, E. \& Öztekin, Ö. (2014). Okul müdürlerinin dönüşümcü liderlik davranışlarının öğretmenlerin örgütsel bağlılığına etkisi: Bir metaanaliz çalışması. Kuram ve Uygulamada Ĕ̌itim Yönetimi, 20(4), 483-500. doi: 10.14527/kuey.2014.019.

Çoğaltay, N., Anar, S. \& Karadağ, E. (2017). Öğretmenlerin tükenmişliğini etkileyen faktörler: cinsiyetin ve medeni durumun etkisine yönelik bir meta-analiz çalışması. Hacettepe Üniversitesi Eğitim Fakültesi Dergisi, 32(3), 695-707. doi: 10.16986/HUJE.2016018517

Dağyar \& Demirel (2015). Probleme Dayalı Öğrenmenin Akademik Başarıya Etkisi: Bir Meta-Analiz Çalışması. Eğitim ve Bilim, 40(181), 139-174.

Diener, E., Scollon, C. N. \& Lucas, R. E. (2004). The evolving concept of subjective well-being: The multifaceted nature of happiness. In P. T. Costa \& I. C. Siegler (Eds.), Advances in cell aging and gerontology (Vol. 15, pp. 187-220). Amsterdam: Elsevier.

Dinçer, S. (2014). Eğitim bilimlerinde uygulamalı metaanaliz. Ankara: Pegem Akademi.

Dipaola, M. F. \& Hoy, W. K.(2005). Organizational citizenship of faculty and achievement of high school students. The High School Journal, 88(3), 35-44.

Duffy, J. A. \& Lilly, J. (2013). Do individual needs moderate the relationships between organizational citizenship behavior, organizational trust and perceived organizational support? Journal of Behavioral and Applied Management, 14(3), 185197.

Eder, P. \& Eisenberger, R. (2008). Perceived organizational support: Reducing the negative influence of coworker withdrawal behavior. Journal of Management, 34(1), 55-68. http://dx.doi.org/10.1177/0149206307309259.

Eisenberger, R., Aselage, J., Sucharski, I. L. \& Jones, J. R. (2004). Perceived organizational support. In Coyle-Shapiro, J. A. M., Shore, L. M., Taylor, M. S. \& Tetrick, L. E. (Eds.), The employment relationship: Psychological and contextual perspectives, 206-225. Oxford, UK: Oxford University Press.

Eisenberger, R., Fasolo, P. \& Davis-LaMastro, V. (1990). Perceived organizational support and employee diligence, commitment, and innovation. Journal of Applied Psychology, 75(1), 51-59. http://dx.doi.org/10.1037/0021-9010.75.1.51.
Eisenberger, R., Huntington, R., Hutchison, S. \& Sowa, D. (1986). Perceived organizational support. Journal of Applied Psychology, 71(3), 500-507. http://dx.doi.org/10.1037/0021-9010.71.3.500.

Eisenberger, R. \& Stinglhamber, F. (2011). Perceived organizational support: Fostering enthusiastic and productive employees. Washington, DC, US: American Psychological Association. http://dx.doi.org/10.1037/12318-000.

Erdaş, K. D. (2010). Lider-üye mübadelesi, algllanan örgütsel destek ve öz denetim kişilik özelliğinin örgütsel vatandaşlık davranışları üzerindeki etkileri (Yayımlanmamış yüksek lisans tezi). Hacettepe Üniversitesi Sosyal Bilimler Enstitüsü, Ankara.

Edwards, M. R. \& Peccei, R. (2010). Perceived organizational support, organizational identification, and employee outcomes: Testing a simultaneous multifoci model. Journal of Personnel Psychology, 9(1), 17-26. http://dx.doi.org/10.1027/18665888/a000007.

Fay, D. \& Frese, M. (2001). The concept of personal initiative: An overview of validity studies. Human Performance, 14(1), 97-124. http://dx.doi.org/10.1207/S15327043HUP1401_06

Hoy, W. K, Tarter, C. J. \& Witkoskie, L. (1992). Faculty trust in colleagues: linking the principal with school effectiveness. Journal of Research and Development in Education, 26, 38-45.

Howes, R., Citera, M. \& Cropanzano, J. (1995). Goal hierarchies and plan revision. Motivation and Emotion, 19, 77-98.

Jawahar, I. M., Stone, T. H. \& Kisamore, J. L. (2007). Role conflict and burnout: The direct and moderating effects of political skill and perceived organizational support on burnout dimensions. International Journal of Stress Management, 14(2), 142-159. http://dx.doi.org/10.1037/1072-5245.14.2.142.

Jebeli, M. J. \& Etebarian, A. (2015). Perceived organizational support and organizational citizenship behavior. MAGNT Research Report,3(4), 153-158. DOI: $\quad$ dx.doi.org/14.9831/1444-8939.2015/34/MAGNT.15.

Kalkan, F. (2017). The Effect of gender on school administrators and teachers' perceptions of learning organization: A meta-analysis study. Eğitim ve Bilim, 42(191),165-183.

https://doi.org/10.15390/EB.2017.5033Kanungo, R. N. (1982). Measurement of job and work involvement. Journal of Applied Psychology, 67(3), 341-349. http://dx.doi.org/10.1037/00219010.67.3.341.

Kaufman, J. D., Stamper, C. L. \& Tesluk, P. E. (2001). Do supportive organizations make for good corporate 
citizens? Journal of Managerial Issues, 13(4), 436449.

Kurtessis, J. N., Eisenberger, R., Ford, M. T., Buffardi, L. C., Stewart, K. A. \& Adis, C. S. (2017). Perceived organizational support: A meta-analytic evaluation of organizational support theory. Journal of Management, $\quad 43(6), \quad$ 1854-1884. http://dx.doi.org/10.1177/0149206315575554.

Landis J. R. \& Koch G. G. (1977). The measurement of observer agreement for categorical data. Biometrics. 33(1):159-74.

Leary, H. M. (2012). Self-directed learning in problembased learning versus traditional lecture-based learning: A meta-analysis. (Unpublished doctoral dissertation). Utah State University, Utah, USA

Mael, F. A. \& Ashforth, B. E. (1995). Loyal from day one: Biodata, organizational identification, and turnover among newcomers. Personnel Psychology, 48(2), 309-333. http://dx.doi.org/10.1111/j.17446570.1995.tb01759.x

Maslach, C. (1982). Burnout: The cost of caring. Englewood Cliffs, New-Jersey: Prentice Hall.

Ng, T. W. H. (2015). The incremental validity of organizational commitment, organizational trust, and organizational identification homas. Journal of Vocational Behavior 88, 154-163.

Organ, D. W. (1988). Issues in organization and management series. Organizational citizenship behavior: The good soldier syndrome. Lexington, MA, England: Lexington Books/D. C. Heath and Com.

Orthner, D. K. \& Pittman, J. F. (1986). Family contributions to work commitment. Journal of Marriage and the Family, 48(3), 573-581. http://dx.doi.org/10.2307/352043

Panaccio, A. \& Vandenberghe, C. (2009). Perceived organizational support, organizational commitment and psychological well-being: A longitudinal study. Journal of Vocational Behavior, 75(2), 224-236.

Parker, S. K. \& Collins, C. G. (2010). Taking stock: Integrating and differentiating multiple proactive behaviors, Journal of Management, 36(3), 655-56. http://dx.doi.org/10.1177/0149206308321554.

Piercy, N. F., Cravens, D. W., Lane, N. \& Vorhies, D. W. (2006). Driving organizational citizenship behaviors and salespersons in role behavior performance: The role of management control and perceived organizational support. Journal of the Academy of Marketing Science, 34(2), 244-62.

Radin, D. İ. \& Ferrari, D. C. (1991). Effects of consciousness on the fall of dice: A Meta-Analysis. Journal of Scientific Exploration, 5(1), 6 1-83.
Randall, M. L., Cropanzano, R., Bormann, C. A. \& Birjulin, A. (1999). Organizational politics and organizational support as predictors of work attitudes, job performance, and organizational citizenship behavior. Journal of Organizational Behavior, 20(2), 159-174. http://dx.doi.org/10.1002/(SICI)10991379(199903)20:2<159::AID-JOB881>3.0.CO;2-7.

Rhoades, L., Eisenberger, R. \& Armeli, S. (2001). Affective commitment to the organization: The contribution of perceived organizational support. Journal of Applied Psychology, 86(5), 825-836. http://dx.doi.org/10.1037/0021-9010.86.5.825.

Rhoades, L. \& Eisenberger, R. (2002). Perceived organizational support: A review of the literature. Journal of Applied Psychology, 87, 698714.

Scott, S. \& Lane, V. (2000). A Stakeholder Approach to Organizational Identity. The Academy of Management Review, 25(1), 43-62.

Sezgin, F. (2005). Örgütsel vatandaşlık davranışları: Kavramsal bir çözümleme ve okul açısından bazı çıkarımlar. Gazi Üniversitesi Gazi Eğitim Fakültesi Dergisi, 25(1), 317-339.

Shore, L. M. \& Shore, T. H. (1995). Perceived organizational support and organizational justice. In R. Cropanzano \& M. Kacmar (Eds.), Organizational politics, justice and support: Managing the social climate in the work place (pp. 149-164). Westport, CT: Quorum.

Shore, L. M. \& Tetrick, L. E. (1991). A construct validity study of the Survey of Perceived Organizational Support. Journal of Applied Psychology, 76(5), 637643. http://dx.doi.org/10.1037/0021-9010.76.5.637.

Silbert, L. T. (2005). The effect of tangible rewards on perceived organizational support (Unpublished master's thesis), University of Waterloo, Canada

Sluss, D. M., Klimchak, M. \& Holmes, J. J. (2008). Perceived organizational support as a mediator between relational exchange and organizational identification. Journal of Vocational Behavior, 73(3), 457-464. http://dx.doi.org/10.1016/j.jvb.2008.09.001.

Tarter, C. J., Bliss, J. R. \& Hoy, W. K. (1989). School characteristics and faculty trust in schools. Educational Administration Quarterly, 25(3), 294308 .

Turunç, Ö. \& Çelik, M. (2010). Çalışanların algıladıkları örgütsel destek ve iş stresinin örgütsel özdeşleşme ve iş performansına etkisi, Yönetim ve Ekonomi, 17(2), 183-206.

Walters, G. \& Raybould, M. (2007). Burnout and perceived organisational support among front-line hospitality employees, Journal of Hospitality and 
Tourism Management, 14(2), 144-156. doi:10.1375/jhtm.14.2.144

Wayne, S. J. \& Green, S. A. (1993). The effects of leadermember exchange on employee citizenship and impression management behavior. Human Relations, 46(12), 1431-1440. https://doi.org/10.1177/001872679304601204.

Wayne, S. J., Shore, L. M. \& Liden, R. C. (1997). Perceived organizational support and leader-member exchange: A social exchange perspective. Academy of Management Journal, 40(1), 82-111. http://dx.doi.org/10.2307/257021.

Wickramasinghe, D. \& Wickramasinghe, V. (2011). Perceived organisational support, job involvement and turnover intention in lean production in Sri Lanka. The International Journal of Advanced Manufacturing Technology, 55(5-8), 817-830.

Yoshimura, K. E. (2003). Employee traits, perceived organizational support, supervisory communication, affective commitment and intent to leave: Group differences (Unpublished master's thesis). North Carolina State University, Raleigh NC.

Zhai, Q., Wang, S. \& Weadon, H. (2017). Thriving at work as a mediator of the relationship between workplace support and life satisfaction. Journal of Management \& Organization, 1-17. doi:10.1017/jmo.2017.62.

Zagenczyk, T. J. (2001). A social influence analysis of perceived organizational support ((Unpublished doctoral dissertation), University of Pittsburgh, Pennsylvania, USA.

\section{META ANALIZE DAHIL EDİLEN ARAŞTIRMALARIN KAYNAKÇASI}

Alcan, E.E. (2018). Öğretmenlerin örgütsel destek, örgütsel özdeşleşme ve örgütsel bağlllık alglları arasındaki ilişki (Yayımlanmamış doktora tezi), İstanbul Sabahattin Zaim Üniversitesi, Sosyal Bilimler Enstitüsü, İstanbul.

Bakan, İ., Erşahan, B., Büyükbeşe, T., Okumuş, M.T. \& Akmeşe, A. (2017). Öğretmenlerin işe yönelik davranışlarında (örgütsel stres, iş yükü, işten ayrılma niyeti ve iş tükenmişliği) örgütsel desteğin rolü: Bir alan araştırması. Internatıonal Journal of Discıplınes Economics \& Administratıve Sciences Studies, 3(4), 444-464.

Büyükgöze, H. \& Kavak, Y. (2017). Algılanan örgütsel destek ve pozitif psikolojik sermaye ilişkisi: Lise öğretmenleri örnekleminde bir inceleme. Kuram ve Uygulamada Eğitim Yönetimi, 23(1), 1-32. doi: 10.14527/kuey.2017.001.
Çakır, S. \& Nartgün, Ş.S. (2018). Ortaöğretim öğretmenlerinin örgütsel destek ile sosyal kaytarma davranış düzeyleri. Uluslararası Sosyal Araştırmalar Dergisi, 11(55), 555-570.

Demir, K. (2015). The effect of organizational justice and perceived organizational support on organizational citizenship behaviors: The mediating role of organizational identification. Eurasian Journal of Educational Research, 60, 131-148. Doi: 10.14689/ejer.2015.60.8 .

Eğriboyun, D. (2013). Ortaöğretim okullarında görev yapan yönetici ve ögrretmenlerin örgütsel güven, örgütsel destek ve örgütsel bağlllıkları arasındaki ilişki (Bolu ili Örneği) (Yayımlanmamış doktora tezi), Abant İzzet Baysal Üniversitesi, Eğitim Bilimleri Enstitüsü, Bolu.

Erdoğan, B., Kraimer, M.L. \& Liden, R. C. (2004). Work value congruence and intrinsic career success: the compensatory roles of leader-member exchange and perceived organizational support. Personnel psychology. 57. 305-332. doi: 10.1111/j.17446570.2004.tb02493.x

Güngör, S. K. \& İlişen, E. (2018). Öğretmenlerin örgütsel destek algıları ile örgütsel bağlılıkları arasındaki ilişsinin analizi, Ahi Evran Universitesi Kırşehir Eğitim Fakültesi Dergisi, 19 (1), 962-977.

Hatipoğlu, Z. (2015). Öğretmenlerin örgütsel destek algılarının örgütsel özdeşleşme seviyelerine etkisi: Ankara Çankaya ilçesinde bir uygulama (Yayımlanmamış yüksek lisans tezi), Çankaya Üniversitesi, Sosyal Bilimler Enstitüsü, Ankara.

Işık, M. \& Kama, A. (2018). Algılanan örgütsel desteğin işgören performansına etkisinde işe adanmışlığın aracı etkisi. Anemon Muş Alparslan Üniversitesi Sosyal Bilimler Dergisi, 6(3), 395-403.

Karakurt, A. (2012). Öğretmenlerin işyerinde yalnızlık düzeyinin örgütsel destek ve bazl değişkenler açısından incelenmesi (Yayımlanmamış yüksek lisans tezi), Necmettin Erbakan Üniversitesi, Eğitim Bilimleri Enstitüsü, Konya.

Kartal, S. E., Yirci, R. \& Özdemir, T. Y. (2015). Öğretmenlerde algılanan örgütsel destek düzeyi ile yaşam memnuniyeti arasındaki ilişkinin incelenmesi. Dicle Üniversitesi Ziya Gökalp Eğitim Fakültesi Dergisi, 24, 477-504.

Kayasandık, A. E. (2017). Öğretmenlerin bireysel yenilikçilik ve değişime hazır olmalarının algılanan örgütsel destek ile ilişkisi: Samsun'da bir çalışma. The Journal of Academic Social Science, 5(54), 511-527.

Köse, A. (2015). İ̧se angaje olma ile örgütsel destek algisl ve örgüt iklimi arasındaki ilişki (Kahramanmaraş ili örneği) (Yayımlanmamış 
doktora tezi). Kahramanmaraş Sütçü İmam Üniversitesi, Sosyal Bilimler Enstitüsü, Kahramanmaraş.

Nartgün, Ş. S. \& Kalay, M. (2014). Öğretmenlerin örgütsel destek, örgütsel özdeşleşme ile örgütsel sinizm düzeylerine ilişkin görüşleri. Literature and History of Turkish or Turkic, 9(2), 1361-1376

Nayır, F. (2011). Illköğretim okulu yöneticilerinin ögrretmenlere sağlanan örgütsel desteğe ilişkin görüsleri, öğretmenlerin örgütsel destek algisl ve örgütsel bağlllıkla ilişkisi (Yayımlanmamış doktora tezi), Ankara Üniversitesi, Eğitim Bilimleri Enstitüsü, Ankara.

Nayır, F. \& Taşkın, P. (2017). Eğitim örgütlerinde örgütsel destek algısı ile inisiyatif alma davranışı arasındaki ilişki. Yüzüncü Yıl Üniversitesi Eğitim Fakültesi Dergisi, 14(1), 1319-1356.

Özek, B.Y. (2016). İlköğretim okulu ögretmenlerinin algıladıkları örgütsel destek ile örgütsel güven düzeyleri arasindaki ilișkinin incelenmesi (Yayımlanmamıș yüksek lisans tezi), Gazi Üniversitesi, Eğitim Bilimleri Enstitüsü, Ankara.

Polat, S. \& Aktop, E. (2010). Öğretmenlerin duygusa zeka ve örgütsel destek algılarının girişimcilik davranışlarına etkisi. Akademik Bakış Dergisi, 22, 120.

Taşkın, S. (2016). Öğretmenlerin örgütsel destek ve örgütsel özdeşleşme düzeyleri ile insiyatif iklimi arasındaki ilişki (Yayımlanmamış yüksek lisans tezi), Abant İzzet Baysal Üniversitesi, Eğitim Bilimleri Enstitüsü, Bolu.

Uzun, T. (2018a). Okullarda algılanan örgütsel destek, örgütsel güven, duygusal bağl1lık ve örgütsel vatandaşlık davranışı arasındaki ilişkiler. OPUS Uluslararası Toplum Araştırmaları Dergisi, 8(15), 958-987. DOI: 10.26466/opus.418335.

Uzun, T. (2018b). Öğretmenlerin algıladığı örgütsel destek ile örgütsel özdeşleşme ve işten ayrılma niyeti arasındaki ilişki: Örgütsel güvenin aracı rolü. Karadeniz Sosyal Bilimler Dergisi, 10(18), 133-155.

Y1lmaz, D. (2014). Dağıtılmış liderliğin örgütsel güven ile algilanan örgütsel destek ve okul başarısıyla ilişkisi (Yayımlanmamış doktora tezi), Eskişehir Osmangazi Üniversitesi, Eğitim Bilimleri Enstitüsü, Eskişehir. 
Ek 1: Meta-Analize Dâhil Edilen Araştırmaların Analiz Tablosu

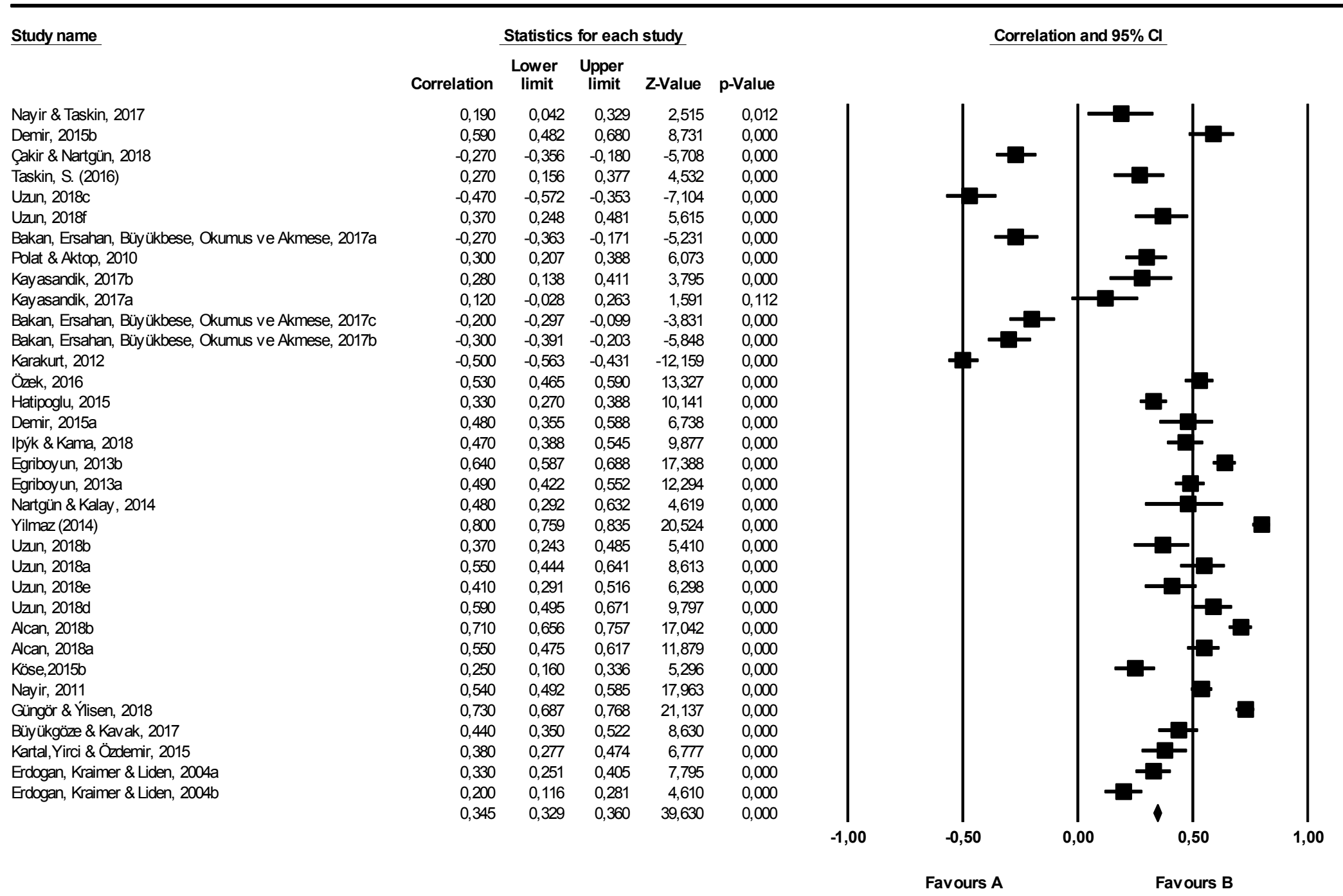

Meta Analysis 